\title{
The Synthesis of (+)-Marmelo Lactones A and B and the Assignment of the Absolute Configurations of Marmelo Lactones
}

\author{
Yoshihiro Nishida, Hiroshi OHrui and Hiroshi Meguro \\ Department of Food Chemistry, Faculty of Agriculture, \\ Tohoku University, Amamiyamachi-Tsutsumidori, Sendai 980, Japan
}

Received October 6, 1983

\begin{abstract}
(+)-Marmelo Lactones A (VA) and B (VB) were synthesized from erythro- $\gamma$-methyl-L-glutamic acid (IA) and threo acid (IB), respectively. The absolute configurations of natural marmelo lactones were thus determined to be $(2 R, 4 S)$ for (+)-marmelo lactone $\mathbf{A}$ and $(2 R, 4 R)$ for (-)-marmelo lactone B.
\end{abstract}

In 1980 Tsuneya et al. isolated two novel terpene lactones from the fruit of a quince (Cydonia oblonga MILL, marmelo) as the main flavor components of the fruit. ${ }^{1)}$ They were identified as 2,4-cis or trans stereoisomers of 2,7-dimethyl-5E, 7-octadien-4-olide and were named $(+)$-marmelo lactone $\mathbf{A}\left([\alpha]_{D}=\right.$ $\left.+103^{\circ}\right)$ and $(-)$-marmelo lactone $\mathbf{B}\left([\alpha]_{\mathrm{D}}=\right.$ $\left.-20^{\circ}\right) .{ }^{1)}$ The absolute configurations of the chiral centers at $\mathrm{C} 2$ and $\mathrm{C} 4$ were first proposed to be $(2 R, 4 R)$ for $(+)$-A and $(2 R, 4 S)$ for $(-)$ $B$ on the basis of NMR and circular dichroism (CD) ${ }^{2)}$ However, the stereochemistry has not previously been synthetically established.

In order to confirm their configurations, we attempted to derive the two optically active marmelo lactones from compounds with known configurations. In our previous com- munication, ${ }^{3)}$ we outlined the synthesis and revised the absolute configurations as (+)lactone $\mathbf{A}$ having a $(2 R, 4 S)$ configuration and (-)-lactone B having a $(2 R, 4 R)$ configuration. In this report, we describe the results in detail with the experiments.

The synthetic routes to $(4 S)$-marmelo lactones are depicted in Figs. 2 and 3. The stereochemistries of the key starting materials, erythro- $\gamma$-methyl-L-glutamic acid (IA) and threo acid (IB) have already been established

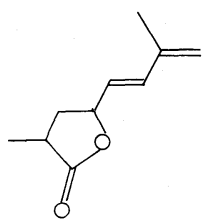

FIG. 1.

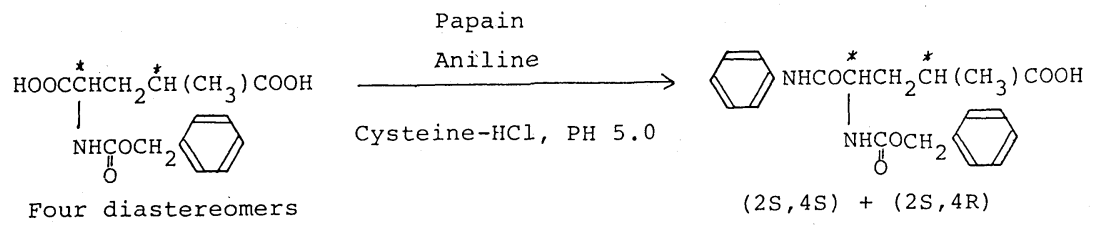

Four diastereomers

$\mathrm{HOOC} \stackrel{*}{\mathrm{CH}}\left(\mathrm{NH}_{2}\right) \mathrm{CH}_{2} \stackrel{*}{\mathrm{C}} \mathrm{H}\left(\mathrm{CH}_{3}\right) \mathrm{COOH}$

$(I A)+(I B)$

1) $\mathrm{H}_{2} / \mathrm{Pd}$ black, $\mathrm{CH}_{3} \mathrm{OH}$

2) $4 \mathrm{~N} \mathrm{HCl,} \mathrm{reflux}$

Fig. 2. Enzymatic Resolution of $\gamma$-Methyl-D,L-glutamic Acid. 
since IA is known to occur in plants. ${ }^{4 \sim 7)}$ There have been some reports for the preparation of the acids: $\left.{ }^{5} \sim 7\right)$ they have been derived from the naturally occurring $\gamma$-methylene-L-glutamic $\operatorname{acid}^{5)}$ and then from the synthetic mixture of $\mathrm{D}, \mathrm{L}-\gamma$-methyl glutamic acid via the enzymatic resolution of the carbobenzoxy amide with papain. ${ }^{7)}$ In this report, we developed the enzymatic resolution with papain for the preparative purpose. The procedure was almost the same as the resolution of $N$-carbobenzoxyD,L-glutamic acid. ${ }^{8)}$ The oily deposits of $N$-carbobenzoxy- $\gamma$-methyl-L-glutamic acid anilide $\left([\alpha]_{\mathrm{D}}^{23}=-15^{\circ}\right)$ was separated from the $\mathrm{D}$-acid and then deprotected to give a mixture of IA and IB as a white powder. $\left([\alpha]_{\mathrm{D}}^{23}=\right.$ $+27^{\circ}, \mathrm{mp}=167^{\circ} \mathrm{C}$ ). An anion exchange column chromatography gave an erythro rich fraction $\left(\mathbf{I A}+c a .20 \% \mathbf{I B},[\alpha]_{\mathrm{D}}^{23}+25.1^{\circ}\right.$ in $6 \mathrm{~N}$ $\mathrm{HCl})$ and a threo rich fraction $(\mathbf{I B}+c a$. $10 \% \mathbf{I A},[\alpha]_{\mathrm{D}}^{23}+43.5^{\circ}$ in $\left.6 \mathrm{~N} \mathrm{HCl}\right)$. The minor diastereomers were estimated roughly by the ${ }^{13} \mathrm{C}$-NMR signal of the $\gamma$-methyl group in $\mathbf{D}_{2} \mathrm{O}: \mathbf{I A}=20.2 \mathrm{ppm}$ and $\mathbf{I B}=20.0 \mathrm{ppm}$. The assignment of these fractions as erythro and threo was carried out on the basis of their $[\alpha]_{D}$ values and the order of elution, since the threo acid has been reported as more dextrotatory ${ }^{6)}$ and faster eluting than the erythro acid. ${ }^{5)}$ The erythro rich fraction (IA) and threo rich one (IB) were used as the starting materials without further purification, since (a) all the reactions were known to proceed with retention of the configurations, ${ }^{12)}$ (b) the minor diastereomer could be checked by NMR and/or HPLC during the reaction steps, (c) the two diastereomers were expected to react in almost the same yield, and (d) the isolation of the final compounds VA and VB was possible by the chromatography.

Treatment of IA with $\mathrm{NaNO}_{2}$ and $\mathrm{H}_{2} \mathrm{SO}_{4}$ gave the lactone (IIA) as a waxy solid in a
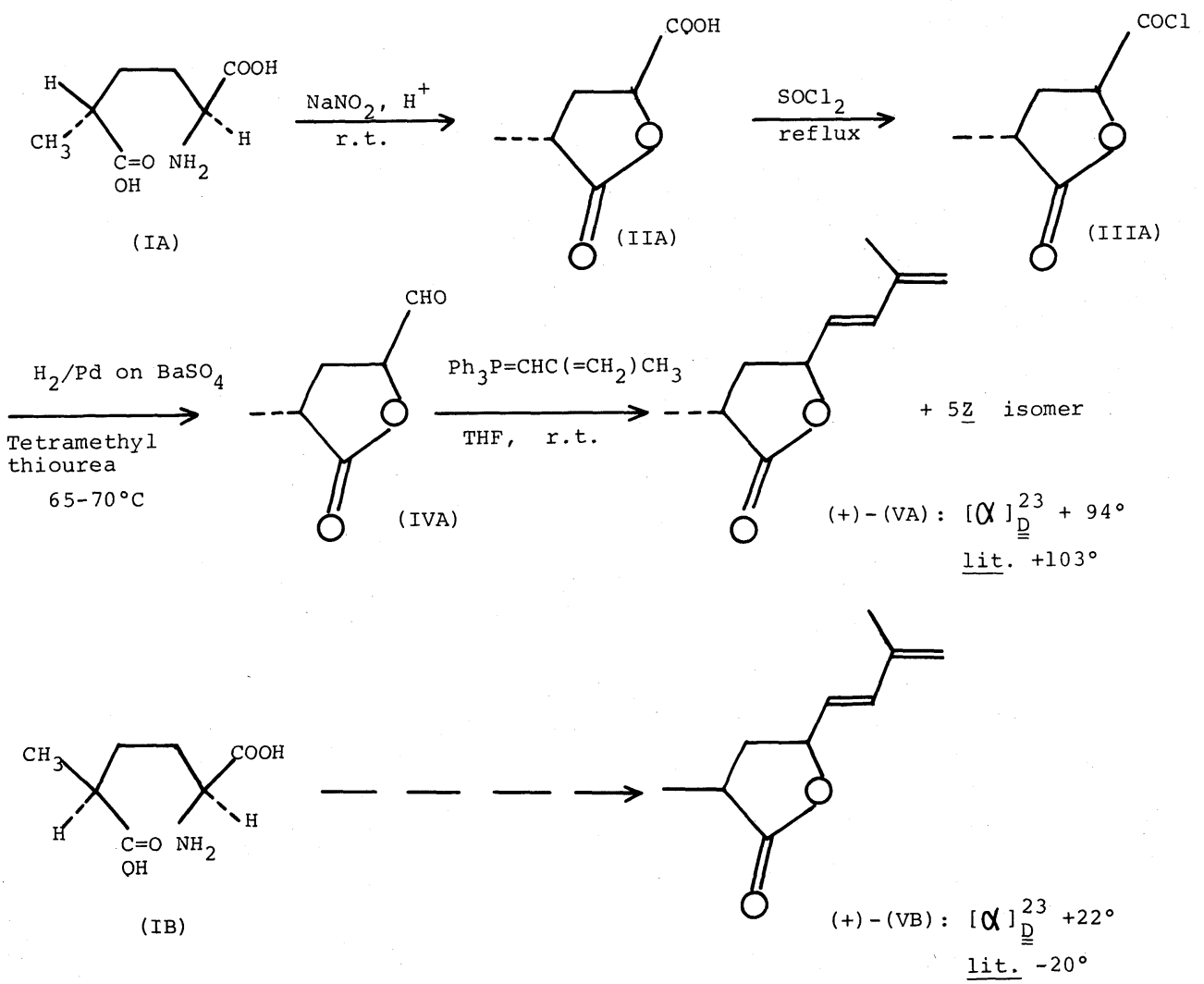

FIG. 3. Preparation of (+)-Marmelo Lactone A (VA), and (+)-Marmelo Lactone B (VB). 




FIG. 4. HPLC Pattern of the Mixture of Four Isomers of Marmelo Lactones Obtained from the IA Rich Compound.

Column, porasil (SS05), $4.5 \mathrm{~mm} \phi \times 250 \mathrm{~mm}$; solvent, isooctane-isopropyl alcohol $=40: 1$; flow rate, $2.5 \mathrm{ml} / \mathrm{min}$; chart speed, $10 \mathrm{~nm} / \mathrm{min}$; UV detector at $230 \mathrm{~nm}$. (a) $5 Z$ Marmelo Lactone B ; (b) $5 Z$ Marmelo Lactone A; (c) Marmelo Lactone A (VA); (d) Marmelo Lactone B (VB).

$70 \sim 80 \%$ yield.$^{9,10)}$ The acid chloride (IIIA), which was quantitatively obtained as a syrup by treating IIA with $\mathrm{SOCl}_{2}$ under reflux ${ }^{11)}$ was converted to the aldehyde (IVA) by Rosenmund reduction. ${ }^{12 \sim 14)}$ Finally, a Wittig reaction of IVA with triphenylphosphonium methallylid ${ }^{16)}$ gave a mixture of the major VA, its $5 Z$ and minor VB isomers. The HPLC analysis showed that the initial ratio of IA and IB was almost maintained to the final step (Fig. 4). From the mixture, VA was isolated by silica gel column chromatography in a total yield of $10 \sim 30 \%$. VA: $[\alpha]_{\mathrm{D}}^{23}$ $+93.6^{\circ}$ in methanol, lit. ${ }^{2}+103^{\circ}$. The ${ }^{1} \mathrm{H}$ $\mathrm{NMR},{ }^{13} \mathrm{C}-\mathrm{NMR}$ and mass spectral data of VA agreed with those of (+)-marmelo lactone $\mathbf{A}$. Here, the $5 E$ and $5 Z$ isomers of VA and VB were readily characterized from the $\mathrm{J}_{\mathrm{H} 5, \mathrm{H} 6}$ values of ${ }^{1} \mathrm{H}-\mathrm{NMR}$ : the $5 \mathrm{Z}$ isomer $^{17)}$ gave lower values $(9.52 \mathrm{~Hz})$ than the $5 E$ isomer $(15.6 \mathrm{~Hz})$.

In a similar way, VB was prepared from the IB rich fraction in a $10 \sim 30 \%$ yield. VB: $[\alpha]_{\mathrm{D}}^{23}+21.8^{\circ}$ in methanol, lit. ${ }^{2)}-20^{\circ}$ for $(-)$ lactone B. The other spectral data of VB agreed with those of (-)-marmelo lactone $\mathbf{B}$. The optical purities of VA and VB could be estimated to be more than $90 \%$ from their values of optical rotation, although this was not checked by any other method.

Since all the reactions described above were known to proceed with retention of configurations, the absolute configurations of natural (+)-marmelo lactone $\mathbf{A}$ and ( - )-marmelo lactone $\mathbf{B}$ should be $(2 R, 4 S)$ and $(2 R, 4 R)$, respectively.

In conclusion, (+)-marmelo lactones $\mathbf{A}$ and B were synthesized from erythro- and threo- $\gamma$ methyl-L-glutamic acid, respectively, in a moderate yield. The absolute configurations of marmelo lactone $\mathbf{A}$ and $\mathbf{B}$ were thus established synthetically and revised ${ }^{2,3)}$ to be $(2 R, 4 S)$ for $(+)$-lactone $\mathbf{A}$ and $(2 R, 4 R)$ for (-)-lactone $\mathbf{B}$.

The syntheses of (-)-marmelo lactones $\mathbf{A}$ and $\mathbf{B}$ from D-glutamic acid have been reported in other papers. ${ }^{15)}$

\section{EXPERIMENTAL}

All melting points and boiling points were uncorrected. IR spectra were recorded on a Jasco A-202 spectrometer. NMR spectra were measured on a JEOL JNM-FX 100 Fourier transform spectrometer in $\mathrm{CDCl}_{3}$ with TMS as an internal standard, unless otherwise stated. Direct mass spectra were recorded on a Hitachi M-52 spectrometer and CD spectra on a Dichrograph Mark III-J. Specific 
rotations were measured on a Jasco ORD/UV-5 at $589 \mathrm{~nm}$. HPLC was performed with a Jasco TRIROTAR equipped with a Jasco UV/DEC-100-II. Kiesel gel 60 $\mathrm{GF}_{254}$ (Merck) was used for the analytical and preparative TLC.

Enzymatic resolution of $N$-carbobenzoxy- $\gamma$-methyl-D,Lglutamic acid. The mixture of diastereomers of carbobenzoxy- $\gamma$-methyl-D,L-glutamic acid obtained as a crude syrup by the method of Done and Fowden ${ }^{4)}$ was used for the resolution. Papain (1:350, digestive powder) was purchased from Wako Chemical Industries, Ltd.

To a solution of the crude racemate $(14 \mathrm{~g})$ in $2 \mathrm{~N} \mathrm{NaOH}$ $(25 \mathrm{ml})$ were added aniline $(8 \mathrm{~g})$, cysteine hydrochloride solution $(0.6 \mathrm{~g}$ in $5 \mathrm{ml}$ of water) and the enzyme solution ( $40 \mathrm{ml}$ of citrate- $\mathrm{NaOH}$ buffer, $\mathrm{pH}=5.0$ ). The reaction mixture was made up to $100 \mathrm{ml}$ by the addition of water and incubated at $40^{\circ} \mathrm{C}$. $N$-Carbobenzoxy- $\gamma$-methyl-Lglutamic acid anilide (CBZ anilide) soon started to precipitate as an oily product. After incubating for $12 \mathrm{hr}$ at $40^{\circ} \mathrm{C}$, the solution was cooled to $4^{\circ} \mathrm{C}$ and extracted with $\mathrm{CHCl}_{3}(30 \mathrm{ml} \times 3)$. The extracts were combined, washed with sat. $\mathrm{NaCl}$, dil. $\mathrm{HCl}$ and water, and then dried over $\mathrm{Na}_{2} \mathrm{SO}_{4}$. Evaporation of the solvent in vacuo gave $\mathrm{CBZ}$ anilide as a white powder, $7 \mathrm{~g}(80 \%$ of the theoretical yield), mp. $145 \sim 153^{\circ} \mathrm{C}$. Anal. Found: C, 64. 89; H, 6.00; $\mathrm{N}$, 7.45. Calcd. for $\mathrm{C}_{20} \mathrm{H}_{22} \mathrm{O}_{5} \mathrm{~N}_{2}: \mathrm{C}, 64.85 ; \mathrm{H}, 5.98 ; \mathrm{N}$, 7.56. ${ }^{1} \mathrm{H}-\mathrm{NMR}: 1.3(3 \mathrm{H}, \mathrm{d}), 1.7 \sim 2.2(2 \mathrm{H}, \mathrm{m}), 2.3 \sim 2.9$ $(1 \mathrm{H}, \mathrm{m}), 4.5 \sim 4.8(1 \mathrm{H}, \mathrm{m}), 5.1(2 \mathrm{H}, \mathrm{s}), 6.0(2 \mathrm{H}$, broad $)$, $7.0 \sim 7.6(10 \mathrm{H}, \mathrm{m}), 9.2 \sim 9.3(1 \mathrm{H}$, broad $)$.

(+)-Erythro- $\gamma$-methyl-L-glutamic acid (IA) and (+)threo- $\gamma$-methyl-L-glutamic acid $(I B)$. The CBZ anilide $(7 \mathrm{~g})$ was dissolved in methanol $(50 \mathrm{ml})$ containing Pd-black $(100 \mathrm{ml})$ and hydrogenated under atmospheric pressure at room temperature, while the reaction was checked with TLC: CBZ anilide, $R f=0.84(\mathrm{BuOH}: \mathrm{AcOH}: \mathrm{MeOH}=$ $45: 4: 8$, UV detection); $\gamma$-methyl-L-glutamic acid anilide, $R f=0.68\left(\mathrm{BuOH}: \mathrm{AcOH}: \mathrm{H}_{2} \mathrm{O}=4: 1: 1\right.$, ninhydrin detection). After completing the reaction $(2 \sim 3 \mathrm{hr})$, the mixture was concentrated in vacuo to give a syrupy residue $(4.8 \mathrm{~g})$ of $\gamma$-methyl-L-glutamic acid anilide. The crude anilide $(4 \mathrm{~g})$ was dissolved in $4 \mathrm{~N} \mathrm{HCl}(200 \mathrm{ml})$, the solution was refluxed for $12 \mathrm{hr}$ and then cooled to room temperature. The solution was washed with benzene $(20 \mathrm{ml} \times 3)$ to remove the aniline and concentrated under a reduced pressure to give a viscous pale yellow syrup of crude $\gamma$ methyl-L-glutamic acid ( $3 \mathrm{~g})$, which was crystallized from water-acetone, $2.5 \mathrm{~g}$ ( $82 \%$ yield from the $\mathrm{CBZ}$ anilide). ${ }^{13} \mathrm{C}$-NMR showed that this solid was a mixture of IA and IB, $\operatorname{mp} 150 \sim 158^{\circ} \mathrm{C},[\alpha]_{\mathrm{D}}^{23}=+31.5^{\circ}(c=0.5,6 \mathrm{~N} \mathrm{HCl}) .{ }^{1} \mathrm{H}-$ NMR $\delta_{\mathrm{D}_{2} \mathrm{O}}^{\text {DSS }} 1.2(3 \mathrm{H}, \mathrm{d}), 1.8 \sim 2.3(2 \mathrm{H}, \mathrm{m}), 2.5 \sim 2.9(1 \mathrm{H}$, m), $3.8(1 \mathrm{H}, \mathrm{t})$. TLC: $R f=0.33\left(\mathrm{BuOH}: \mathrm{AcOH}: \mathrm{H}_{2} \mathrm{O}=\right.$

\section{$4: 1: 1$, ninhydrin detection).}

Separation of $I A$ and $I B$ by anion exchange column chromatography. The crude mixture of IA and IB (3 g) was mounted on an anion exchange column (Dowex $1, \times 8$, $100 \sim 200$ mesh, acetate form $* 1,3 \mathrm{~cm} \phi \times 80 \mathrm{~cm}$ ) and eluted with $0.2 \mathrm{~N} \mathrm{AcOH}$. The eluent was detected by TLC with $\mathrm{BuOH}-\mathrm{AcOH}-\mathrm{H}_{2} \mathrm{O}(4: 1: 1)$ and the optical rotation at $300 \mathrm{~nm}$. The faster moving fractions, 30 45, (one fraction $=15 \mathrm{~g}$ ) were collected and evaporated in vacuo to give a white solid $(700 \mathrm{mg})$ which was recrystallized from water-acetone to give a IB rich compound, $500 \mathrm{mg}, \mathrm{mp}$ $178^{\circ} \mathrm{C},[\alpha]_{\mathrm{D}}^{23}+43.5^{\circ}(c=0.4,6 \mathrm{~N} \mathrm{HCl})$, lit. $+30.2^{\circ}(c=0.24$, $5 \mathrm{~N} \mathrm{HCl}),{ }^{6)}+22.2^{\circ}(c=0.24,5 \mathrm{~N} \mathrm{HCl}) .{ }^{5)}{ }^{13} \mathrm{C}_{-} \mathrm{NMR}^{* 2}$ $\delta_{\mathrm{D}_{2} \mathrm{O}}^{\text {DSS }}: 20.0,37.4,40.2,56.1,177.2,183.8$. Anal. Found: C, 44.27; $\mathrm{H}, 7.12 ; \mathrm{N}, 8.33$. Calcd. for $\mathrm{C}_{6} \mathrm{H}_{11} \mathrm{O}_{4} \mathrm{~N}: \mathrm{C}, 44.71$; $\mathrm{H}, 6.87 ; \mathrm{N}, 8.69$. The slower fractions, $50 \sim 65$, were collected and evaporated to give a IA rich compound as a syrup $(600 \mathrm{mg})$, which was crystallized from wateracetone, $\mathrm{mp} 170^{\circ} \mathrm{C},[\alpha]_{\mathrm{D}}^{23}+25.1^{\circ}(c=0.41,6 \mathrm{~N} \mathrm{HCl})$, lit. $+22.2^{\circ}(c=0.66,5 \mathrm{~N} \mathrm{HCl}),{ }^{6)}+19.2^{\circ}(c=2.5,6 \mathrm{~N} \mathrm{HCl}) .^{5)}$ ${ }^{13} \mathrm{C}-\mathrm{NMR} \delta_{\mathrm{D}_{2} \mathrm{O}}^{\text {DSS }}: 20.2,37.0,39.9,56.1,177.2,184.4$. Anal. Found: $\mathrm{C}, 44.70 ; \mathrm{H}, 7.05 ; \mathrm{N}, 8.62$. Calcd. for $\mathrm{C}_{6} \mathrm{H}_{11} \mathrm{O}_{4} \mathrm{~N}$ : C, $44.71 ; \mathrm{H}, 6.87 ; \mathrm{N}, 8.69$.

$(2 R, 4 S)$-4-Carboxy-2-methylbutan-4-olide (IIA). To a solution of the $\mathbf{I A}$ rich compound $(1.26 \mathrm{~g})$ in water $(8.5 \mathrm{ml})$ were simultaneously added $2 \mathrm{~N} \mathrm{H}_{2} \mathrm{SO}_{4}(5 \mathrm{ml})$ and $\mathrm{NaNO}_{2}$ ( $720 \mathrm{mg}$ in $5 \mathrm{ml}$ of water) over $20 \mathrm{~min}$. After stirring for $12 \mathrm{hr}$ at room temperature, the solution was evaporated in vacuo to dryness and eluted with hot acetone $(10 \mathrm{ml} \times 3)$. The acetone extracts were combined, dried over $\mathrm{Na}_{2} \mathrm{SO}_{4}$ and concentrated in vacuo to give a viscous syrup ( $1 \mathrm{~g})$ of a crude mixture of IIA containing small amount of IIB. The crude syrup was distilled under a reduced pressure ( $8 \mathrm{mmHg}, 180 \sim 190^{\circ} \mathrm{C}$ bath temp.) to give a white solid of a IIA rich compound, $700 \mathrm{mg},(69 \%$ from IA), $\mathrm{mp}$ $50 \sim 56^{\circ} \mathrm{C}$. IR $v_{\max }^{\text {film }} \mathrm{cm}^{-1}: 3500(\mathrm{w}), 2950(\mathrm{~m}), 2700 \sim 2500$ (m), 1760 (s). ${ }^{13} \mathrm{C}-\mathrm{NMR}: 15.20,34.03,34.79,73.75,173.85$, 178.76 .

$(2 S, 4 S)$-4-Carboxy-2-methylbutan-4-olide (IIB). In a similar manner to the preparation of IIA, the IB rich compound $(1.26 \mathrm{~g})$ was converted to the IIB rich compound $(760 \mathrm{mg}, 74 \%$ yield from IB) as a viscous syrup, bp $180 \sim 190^{\circ} \mathrm{C}$ bath temperature $/ 8 \mathrm{mmHg}$. IR $v_{\max }^{\text {film }} \mathrm{cm}^{-1}$ : $3500(\mathrm{w}), 2950(\mathrm{~m}), 2700 \sim 2400(\mathrm{~m}), 1760$ (s). ${ }^{13} \mathrm{C}-\mathrm{NMR}$ : 15.41, 32.74, 73.51, 173.94, 178.76. ${ }^{1} \mathrm{H}-\mathrm{NMR}: 1.3(3 \mathrm{H}, \mathrm{d})$, $1.8 \sim 2.2(1 \mathrm{H}, \mathrm{m}), 2.6 \sim 3.0(2 \mathrm{H}, \mathrm{m}), 4.9(1 \mathrm{H}, \mathrm{dd}), 9.2(1 \mathrm{H}$, broad s).

(2R, 4S)-4-Chloroformyl-2-methylbutan-4-olide (IIIA). A mixture of IIA (700 mg) and thionyl chloride (1.3 g) was

*1 The acetate form resin was prepared from the $\mathrm{Cl}$ form $(500 \mathrm{~g})$ by several treatments with $1500 \mathrm{ml}$ of $3 \mathrm{~N} \mathrm{AcONa}$, followed by thoroughly washing with water.

*2 $\quad$ NMR data of I $\sim$ IV were obtained by subtracting the signals due to their minor isomers. 
refluxed for $2 \mathrm{hr}$ and allowed to stand at room temperature for $6 \mathrm{hr}$. After removal of the excess thionyl chloride, the residue was distilled under a reduced pressure to give an oily product of the IIIA rich compound containing a small amount of IIIB (700 mg, 98\% yield from IIA). IR $v_{\max }^{\mathrm{film}} \mathrm{cm}^{-1}: 2950(\mathrm{~m}), 1780(\mathrm{~s}), 1750 \sim 1700(\mathrm{~s}) .{ }^{13} \mathrm{C}-\mathrm{NMR}$ : 15.22, 32.65, 33.94, 73.43, 174.87, 179.40. ${ }^{1} \mathrm{H}-\mathrm{NMR}: 1.3$ $(3 \mathrm{H}, \mathrm{d}), 1.9 \sim 2.2(1 \mathrm{H}, \mathrm{m}), 2.2 \sim 2.5(2 \mathrm{H}, \mathrm{m}), 4.95(1 \mathrm{H}, \mathrm{dd})$.

(2S, 4S)-4-Chloroformyl-2-methylbutan-4-olide (IIIB). In a similar way to the preparation of IIIA, the IIB rich compound $(700 \mathrm{mg}$ ) was converted to the IIIB rich one as an oily product $(700 \mathrm{mg}, 98 \%$ yield from IIB). bp $120 \sim 130^{\circ} \mathrm{C}$ bath temperature $/ 8 \mathrm{mmHg}$. IR $v_{\max }^{\text {film }} \mathrm{cm}^{-1}$ : 2950 (m), 1780 (s), $1750 \sim 1700$ (s). ${ }^{1} \mathrm{H}-\mathrm{NMR}: 1.3(3 \mathrm{H}, \mathrm{d})$, $2.0 \sim 2.2(1 \mathrm{H}, \mathrm{m}), 2.2 \sim 2.5(2 \mathrm{H}, \mathrm{m}), 4.6(1 \mathrm{H}, \mathrm{dd}) .{ }^{13} \mathrm{C}-$ NMR: $15.39,34.11,34.70,73.66,174.28,179.4$.

$(2 R, 4 S)-4-F o r m y l-2-m e t h y l b u t a n-4-o l i d e \quad(I V A)$. To a suspension of $5 \% \mathrm{Pd} / \mathrm{BaSO}_{4}(70 \mathrm{mg})$ in dry toluene $(10 \mathrm{ml})$ was added a toluene solution $(2 \mathrm{ml})$ of the freshly distilled IIIA $(600 \mathrm{mg})$ and tetramethyl thiourea $(0.2 \mathrm{mg})$. Into the solution was passed hydrogen with stirring at $65 \sim 70^{\circ} \mathrm{C}$ for $1 \sim 2 \mathrm{hr}$, while the reaction was checked with TLC $\left(\mathrm{CHCl}_{3}-\mathrm{CH}_{3} \mathrm{OH}=8: 1\right)$ : IIIA, $R f=0.8\left(\mathrm{I}_{2}\right.$ detection $)$; IVA, $R f=0.5 \quad\left(\mathrm{I}_{2}\right.$ or 2,4-dinitrophenylhydrazine detection). After completing the reaction, the reaction mixture was rapidly filtered through a pad of celite to remove the catalyst and concentrated in vacuo to give a crude IVA rich syrup $(500 \mathrm{mg})$ which was diluted with dry THF $(50 \mathrm{ml})$ and used in the next reaction without isolation.

$(2 S, 4 S)$-4-Formyl-2-methylbutan-4-olide $(I V B)$. In the same manner as the preparation of IVA, IIIB rich compound $(600 \mathrm{mg})$ was converted to the crude aldehyde IVB $(500 \mathrm{mg})$, which was used in the next reaction without isolation.

$(2 R, 4 S, 5 E)-2,7-D i m e t h y l-5,7-o c t a d i e n-4-o l i d e,((+)-$ marmelo lactone $A)(V A)$. To a suspension of $\left.\mathrm{Ph}_{3} \mathrm{PCH}_{2} \mathrm{C}\left(=\mathrm{CH}_{2}\right) \mathrm{CH}_{3} \mathrm{Cl}^{16}\right)$ in THF $(20 \mathrm{ml})$ was added $n$ butyllithium $(15 \% \mathrm{w} / \mathrm{w}$ in hexane, $1.8 \mathrm{ml})$. The mixture was stirred for $30 \mathrm{~min}$ at room temperature under $\mathrm{N}_{2}$. To the mixture was added the crude aldehyde (IVA) (500 $\mathrm{mg}$ in $5 \mathrm{ml}$ of $\mathrm{THF}$ ) and the resulting mixture was vigorously shaken for $2 \mathrm{hr}$ at room temperature. This mixture was poured into sat. $\mathrm{NaCl}$ and dried over $\mathrm{Na}_{2} \mathrm{SO}_{4}$. After removing the solvent in vacuo, the residue $(300 \mathrm{mg})$ was chromatographed on a preparative TLC $\left(20 \mathrm{~cm} \times 20 \mathrm{~cm}\right.$, Kieselgel $\left.(7 \mathrm{~g})+\mathrm{AgNO}_{3}(2.6 \mathrm{~g})\right) \mathrm{de}-$ veloped with $n$-hexane-ethyl acetate $(7: 1, \mathrm{v} / \mathrm{v})$. After developing twice with the solvent, the slower moving band was scratched off the plate and eluted with ethyl ether. The ethereal extract was passed through a short silica gel column $(1 \mathrm{~cm} \phi \times 10 \mathrm{~cm})$ and the eluent was concentrated to give an oily product of VA containing a small amount of VB. The mixture was mounted on a silica gel column and eluted with $n$-hexane-ethyl acetate $(8: 1, \mathrm{v} / \mathrm{v})$. The faster moving fractions were collected and evaporated to give an oily product of VA $(120 \mathrm{mg}$ in total of VA from $500 \mathrm{mg}$ of crude IVA). $[\alpha]_{\mathrm{D}}^{23}+93.6^{\circ}$ $\left(c=0.09, \mathrm{CH}_{3} \mathrm{OH}\right) .{ }^{1} \mathrm{H}-\mathrm{NMR}: 1.30(3 \mathrm{H}, \mathrm{d}, J=7.1 \mathrm{~Hz})$, $1.85(3 \mathrm{H}, \mathrm{s}), 2.0 \sim 2.30(2 \mathrm{H}, \mathrm{m}), 2.68(1 \mathrm{H}, \mathrm{m}), 5.04(3 \mathrm{H}$, $\mathrm{m}), 5.62(1 \mathrm{H}, \mathrm{dd}, J=6.1$ and $15.6 \mathrm{~Hz}), 6.38(1 \mathrm{H}, \mathrm{d}, J=$ $15.6 \mathrm{~Hz}) .{ }^{13} \mathrm{C}-\mathrm{NMR}$ : $15.5,18.5,33.7,36.5,77.9,118.6$, $126.6,135.1,140.6,179.7$. MS $m / z: 166\left(\mathrm{M}^{+}\right), 151$ $\left(\mathrm{M}^{+}-\mathrm{CH}_{3}\right), 138,123,109,93,81,69,68,42,41$.

$(2 S, 4 S, 5 E)-2,7-D i m e t h y l-5,7-o c t a d i e n-4-o l i d e \quad(+)-$ marmelo lactone $B)(V B)$. In a similar manner to the preparation of VA, the crude aldehyde (IVB) $(400 \mathrm{mg}$ ) yielded a crude VB rich mixture $(300 \mathrm{mg})$, which was mounted on a silica gel column eluted with $n$-hexane-ethyl acetate $(8: 1, v / v)$. The slower moving fractions were collected to give an oily product of VB $(140 \mathrm{mg}, 27 \%$ yield from IVB). The crude oil was purified by preparative TLC developed with ethyl ether-petroleum ether $(1: 5, \mathrm{v} / \mathrm{v})$ to give VB as an oil, $[\alpha]_{\mathrm{D}}^{23}+21.8^{\circ}\left(c=0.11, \mathrm{CH}_{3} \mathrm{OH}\right) .{ }^{1} \mathrm{H}-$ NMR: $1.29(3 \mathrm{H}, \mathrm{d}, J=6.6 \mathrm{~Hz}), 1.68(1 \mathrm{H}, \mathrm{dd}, J=5.6$ and $12.2 \mathrm{~Hz}), 1.86(3 \mathrm{H}, \mathrm{s}), 2.40 \sim 2.80(2 \mathrm{H}, \mathrm{m}), 4.80(1 \mathrm{H}, \mathrm{m})$, $5.06(2 \mathrm{H}$, broad s), $5.63(1 \mathrm{H}, \mathrm{dd}, J=6.8$ and $15.6 \mathrm{~Hz}), 6.42$ $(1 \mathrm{H}, \mathrm{d}, J=15.6 \mathrm{~Hz}) .{ }^{13} \mathrm{C}-\mathrm{NMR}: 15.3,18.5,36.0,38.2$, 78.7, 118.8, 126.7, 136.3, 140.7, 179.0. MS $m / z: 166\left(\mathrm{M}^{+}\right)$, $151\left(\mathrm{M}^{+}-\mathrm{CH}_{3}\right), 138,123,109,93,81,69,68,42,41$.

\section{REFERENCES}

1) T. Tsuneya, M. Ishihara, H. Shiota and M. Shiga, Agric. Biol. Chem., 44, 957 (1980).

2) M. Ishihara, H. Shiota, T. Tsuneya and M. Shiga, Abstracts of Papers, 24th TEAC Symposium, 1980, p. 95; ibid., 25th TEAC Symposium, 1981, p. 59.

3) Y. Nishida, H. Ohrui and H. Meguro, Agric. Biol. Chem., 47, 2123 (1983).

4) J. Done and L. Fowden, Biochem. J., 51, 451 (1952).

5) J. Blake and L. Fowden, Biochem. J., 92, 136 (1964).

6) H. M. Kagan and A. Meister, Biochemistry, 5, 2423 (1966).

7) A. Meister, J. Biol. Chem., 210, 17 (1954).

8) J. S. Fruton, G. W. Irving and M. Bergmann, J. Biol. Chem., 133, 703 (1940).

9) M. Winiz, L. B. Frankenthal, N. Izumiya, S. M. Birnbaum, C. G. Barker and J. P. Greenstein, J. Am. Chem. Soc., 78, 2423 (1956).

10) K. Koga, M. Taniguchi and S. Yamada, Tetrahedron Lett., 263 (1974).

11) C. Eguchi and A. Kakuta, Bull. Chem. Soc. Jpn., 47, 1704 (1974).

12) R. E. Doolittle, J. H. Tumlinson, A. T. Proveaux and R. R. Heath, J. Chem. Ecol., 6, 473 (1980).

13) Rosenmund, Ber., 51, 585 (1918).

14) E. Mosettig and R. Mozingo, Organic Reactions, 4, 362 (1948). 
15) Y. Nishida, H. Ohrui and H. Meguro, Agric. Biol. Chem., 47, 2969 (1983).

16) J. Wolinski, B. Chollar and M. D. Baird, J. Am.
Chem. Soc., 84, 2775 (1962).

17) Y. Nishida, T. Konno, H. Ohrui and H. Meguro, Agric. Biol. Chem., 47, 2683 (1983). 